\title{
Effect of defoliation frequency and N-P-K fertilization on maidencane
}

\author{
R.S. KALMBACHER AND F.G. MARTIN
}

\begin{abstract}
Maidencane (Panicum hemitomon Schult.), an important grass on Florida and southeastern Gulf Coast fresh-water marsh range, was cut on 3-, 6-, 9-, 12- and 24-week intervals (T) from June to December 1982 and 1983 . Half the plots were fertllized every 6 weeks with 56, 12, and $22 \mathrm{~kg} / \mathrm{ha} N$, P, and K, respectively. Dry matter yield (DM), tiller density (TD), rhizome total nonstructural carbohydrate (TNC), crude protein (CP), and in vitto organic matter digestibility (IVOMD) were determined. DM was reduced with frequent clipping, especially every 3 weeks, and 2-year average DM was described: $1981+660 \mathrm{~T}-22 \mathrm{~T}^{2}$, where $\mathrm{T}$ is weeks between harvest. Fertilized grass yielded more DM $(6,270 \mathrm{~kg} / \mathrm{ha})$ than unfertilized $(4,410)$. TD increased as harvest interval increased. For example TD in April 1983 was TD $=40+19.1$ T. TNC was affected by cutting interval $\left(7.2+0.61 \mathrm{~T}-0.016 \mathrm{~T}^{2}\right)$ but not fertilization. CP and IVOMD declined about 0.5 and 3.0 units, respectively, for each week forage remained on range. Fertilization improved 2-year average CP (yes $=13.3 \%$, no $=11.9 \%$ ), but IVOMD was unaffected. Defoliation of maidencane every 3 to 6 weeks reduced stands and yield, and defoliation intervals longer than 3 to 6 weeks resulted in reduced protein and digestibility. Fertilizer rates and timing of application used in this study did help to maintain yield and tiller density at a higher level than unfertilized grass in the second year.
\end{abstract}

Key Words: Southeastern range, Florida range, fresh water marsh

Maidencane (Panicum hemitomon Schult.) is an important Florida range grass because of its high yield (Long et al. 1986a), prominence in cattle diets during summer (Kalmbacher et al. 1984), and its high forage quality (Long et al. 1986a, 1986b). Maidencane is also an important native grass in southern Louisiana (Williams 1951).

Although Florida range responds positively to fertilization (Killinger 1948, Lewis 1970), it is questionable whether the practice would be practical (Duval and Grelen 1967) when range is a scattered mixture of grasses and forbs growing on infertile, sandy spodosols frequently dominated by shrubs, especially saw palmetto (Serenoa repens (Bartr.) Small). Fertilization of maidencane may be justifiable because this grass usually grows in dense stands.

Since we could find no information about the response of maidencane to any management, we took advantage of a pure stand growing on a uniform site in a pasture. This was not a fresh-water marsh site, where the grass normally grows, but a uniform site that permitted us to draw inferences on dry matter (DM), crude protein (CP) content, in vitro organic matter digestibility (IVOMD), tiller density (TD), total nonstructural carbohydrate (TNC) content of rhizomes, and tissue $P$ and $K$ content of maidencane cut at various maturities, with and without $N, P, K$ fertilization.

\section{Materials and Methods}

A pure stand of maidencane was selected near Bartow, Florida, on a Pomello fine sand (sandy, siliceous, hyperthermic Arenic Haplaquod) with an initial $\mathrm{pH}$ of 5.8 and $1.5 \%$ organic matter content. This maidencane, a very vigorous, strongly rhizomatous ecotype, became PI T29575 at the SCS plant materials center at

\footnotetext{
Authors are professor/agronomist, Ona Agricultural Research Center, Ona Florida, 33865; and professor/statistician, University of Florida, Gainesville 32611. Florida Agr. Exp. Sta. Pap. 7872.

Manuscript accepted 8 December 1987.
}

Brooksville. The experimental area was a fenced-off portion within a Pangola digitgrass (Digitaria decumbens Stent.) pasture which received spring and fall applications of about $50,10,20 \mathrm{~kg} / \mathrm{ha} \mathrm{N}, P$, and $K$, respectively. The area had been grazed November to August for the past 5 years and a single crop of hay was usually cut in October. The experimental area was not grazed during the trial.

The experimental area was cut to $7.5-\mathrm{cm}$ stubble early in May 1982 and 1983, after which maidencane was cut at $3,6,9,12$, and 24-week intervals; each treatment with or without 56,12 , and 22 $\mathrm{kg} / \mathrm{ha} \mathrm{N}, \mathrm{P}$, and $\mathrm{K}$ (Table 1). The experiment was a $2 \times 5$ factorial in application of fertilizer and cutting interval. Experimental design was a randomized, complete block with 4 replications.

The first cutting was made 3 weeks after the initial staging when grass was 30 to $45 \mathrm{~cm}$ tall, which was about the first week in June. Forage was sampled to a $7.5-\mathrm{cm}$ stubble-height with a plot harvester which cut a $0.4 \times 5.20-\mathrm{m}$ swath in each $2.14 \times 6.11-\mathrm{m}$ plot. The remainder of each plot was re-staged to $7.5 \mathrm{~cm}$ after samples were taken. Fertilizer was weighed and applied by hand to all appropriate plots every 6 weeks. The initial fertilization was made in early May in both years, but was discontinued when growth ceased in October. Dolomite was uniformly applied at $2,240 \mathrm{~kg} / \mathrm{ha}$ on 16 December 1982 (subsequent pH measurements in 1983 indicated little pH change). The experiment was sprayed on 2 May 1983 with a 3:1 mixture of 2,4-D (2,4-Dichlorophenoxyacetic acid) and dicamba (2-Methoxy-3,6-dichloro-benzoic acid) at 2.3 liter/ha (formulation of Weedmaster ${ }^{(\mathrm{R})}$ to control broadleaf plants such as Mexican tea (Chenopodium ambrosioides L.) and sedges (Cyperus spp.).

Plots were visually rated in May 1983 for weed contamination, particularly common bermudagrass (Cynodon dactylon $\mathrm{L}$. Pers.), to adjust yield to that of pure maidencane. Harvested maidencane was weighed in the field and a sub-sample $(0.5 \mathrm{~kg})$ was weighed, dried, and re-weighed in order to calculate DM yield/ha. These samples were used for CP (Gallaher et al. 1975, Hambleton 1977), and IVOMD (Moore and Mott 1974) analyses. Tissue P (Jackson 1958) and $\mathrm{K}, \mathrm{Ca}$, and $\mathrm{Mg}$ were determined by atomic absorption. Soil was sampled ( 2 cores, $3 \times 30 \mathrm{~cm}$ ) in each plot every 3 weeks and composited over replications. Rhizomes were dug $(10 \times 15-\mathrm{cm}$ cores) every 3 weeks for yield determination and analyzed for TNC (Smith 1969, Somogyi 1952). Rhizome samples were also composited over replications. Tiller density was determined by counting tillers in a $0.25-\mathrm{m}^{2}$ quadrat in each plot on $4 \mathrm{June} 1982,2$ May and 1 Dec. 1983, and 3 Apr. 1984.

Data were analyzed by analysis of variance. Significant main effects and first order interactions were further investigated using Duncan's multiple range test or regression techniques, depending on whether the factor was qualitative or quantitative. Dates were used as replications for TNC and soil mineral analyses. Soil mineral content from fertilized plots was compared to that from unfertilized plots with a paired $t$-test. Unless otherwise stated, all statistical tests were made with $P<0.05$.

\section{Results \& Discussion}

\section{Dry Matter Yield}

Yields were lower in 1983 than 1982 at more frequent cuttings because stands were weakened after 1 year of treatment (Fig. 1). Cutting every 3 weeks was especially detrimental to yield because maidencane tillers in this treatment did not grow taller than 20 to 
Table 1. Schedule of fertilization, cutting, rhizome, tiller, and soil sampling for maidencane. Bartow, Florida.

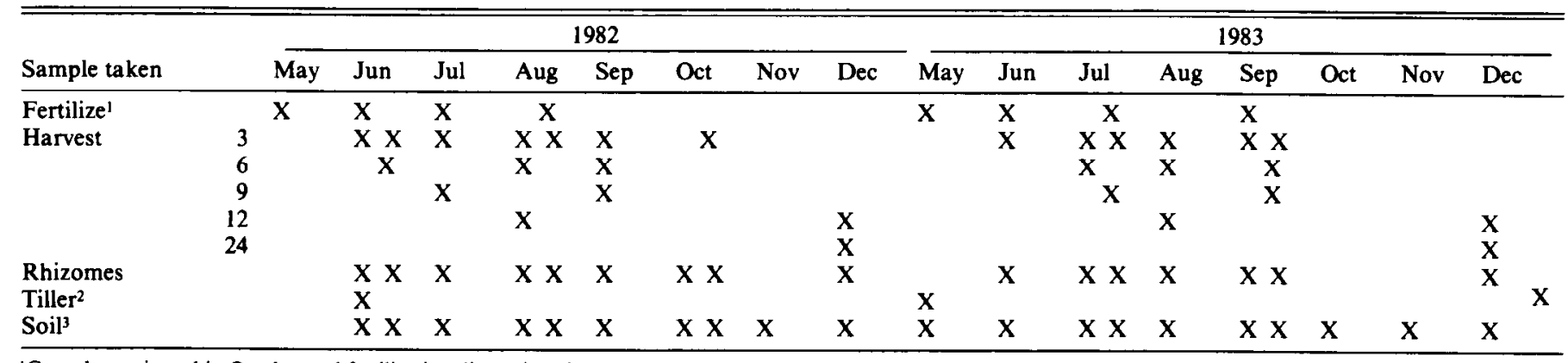

IGrowth terminated in October and fertilization discontinued.

2 Iiller density also determined 3 Apr. 1984

'Soil also sampled on 17 Feb., 4 Apr. 1982, 27 Jan., 8 Mar. 1983.

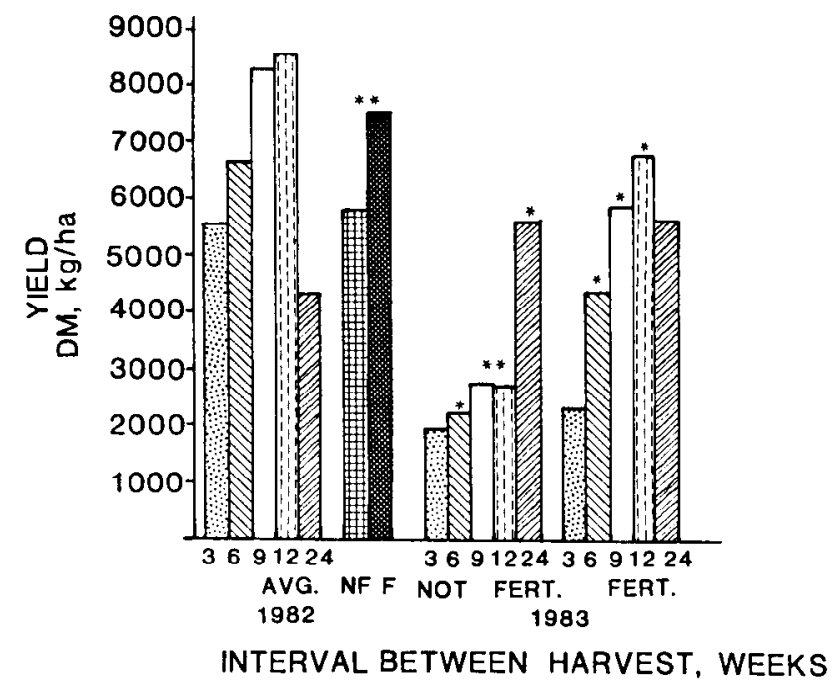

Fig. 1. Total annual dry matter yield (observed) and prediction equations for maidencane yield as affected by interval between harvest and fertilization. Bartow, Florida. 1982 and 1983.

$\dagger T=$ weeks between harvest.

**Difference between not fertilized (NF) and fertilized (F) significant $(\mathrm{P}<0.01)$. Fertilization was 56. 12. $22 \mathrm{~kg} / \mathrm{ha} \mathrm{N}, \mathrm{P}, \mathrm{K}$ every 6 weeks.

$30 \mathrm{~cm}$ before recutting. Such frequent defoliation is similar to that observed on maidencane ponds surrounded by poorly managed pine-palmetto range, which is a situation favoring heavy use of the ponds.

Defoliation at a 12-week interval resulted in the highest average predicted and observed $1982 \mathrm{DM}$ yield of fertilized and unfertilized (no interaction with interval) maidencane (Fig. 1). Fertilized maidencane reached maximum predicted yield in 1983 with an 18-week interval, while unfertilized grass reached maximum predicted yield at a 24-week interval. Yields of unfertilized maidencane at the 24-week interval agreed with 2 reports of annual DM yields of unfertilized maidencane $(4,800$ and $3,470 \mathrm{~kg} / \mathrm{ha})$ from a freshwater marsh in central Florida (Kalmbacher et al. 1984).

Maidencane growth stopped after September, and many of these leaves became senescent and fell. More frequently sampled treatments, such as 3,6, or 9 week, were not sampled after the first week in October because there was no growth (Table 1). Although 3,6,9, and 12-week treatments were 'scheduled' for $10,4,3$, and 2 clip- pings, they were actually sampled $6,3,2$, and 2 times, respectively. Less frequent cutting resulted in greater annual yield than repeated cutting (Fig. 1).

Maidencane herbage yield resulting from 3- to 24-week defoliation intervals from May to December was best described as quadratic because of the loss of senescent leaves in September. Yield response was linear over the 3- to 12-week intervals when the 24-week interval was deleted from the analysis. In $1982 \mathrm{DM}$ yields from fertilized and unfertilized plots (3- to 12-week intervals) were described by the equation: $4560+357 \mathrm{~T}$, where $\mathrm{T}$ is weeks between harvest. In 1983 there was no significant regression for unfertilized maidencane, but DM yield of fertilized maidencane was described: $1140+492 \mathrm{~T}$

Fertilization increased $(P<0.01)$ yield of maidencane in both years. Average observed yield of nonfertilized grass was 5,780 and $3,050 \mathrm{~kg} / \mathrm{ha}$ in 1982 and 1983 , respectively. Fertilized grass yielded 7,550 and $4,900 \mathrm{~kg} / \mathrm{ha}$ in these years, respectively. Average yield was lower in 1983 on both treatments, but addition of fertilizer resulted in less of a decline (35\%) in maidencane yield than when no fertilizer was applied ( $47 \%$ decline).

Maidencane cut at different frequencies did not respond the same to fertilization treatments in 1983 (Fig. 1). When fertilized, maidencane cut at 6-, 9-and 12-week intervals resulted in higher yields than that interval on unfertilized maidencane. When maidencane was cut at 3- or 24-week intervals, this response was not observed. Yield response was quadratic to fertilizer application in 1983 , but the response was linear without fertilizer. The curvilinear response resulted because fertilization of sparse stands (i.e., frequently cut, second year) fostered Cynodon dactylon and Cyperus spp. growth, which suppressed maidencane yield. There was no weed encroachment in the 9-, 12- or 24-week interval treatments, and good stands of maidencane responded positively to fertilizer.

\section{Tiller Density}

Defoliation frequency significantly $(P<0.01)$ influenced tiller density (Fig. 2). Frequent defoliation resulted in reduced tiller density and hence lower yield (Fig. 1). Tiller density was affected by cutting and fertilization in May and December 1983. Fertilizer resulted in a quadratic response with tiller density increasing very rapidly between 3- and 9-week intervals and declining at the 24week cutting interval. This response was similar to that of yield (Fig. 1). Without fertilizer, tiller density and yield were linear or nearly so.

Initial tiller density in June 1982 averaged 650 tillers $/ \mathrm{m}^{2}$. By May 1983 tiller density was less than the initial number in 3-, 6-, 9-, and 12-week cutting intervals on nonfertilized plots (Fig. 2). Tiller density in May 1983 in fertilized treatments cut at 9-, 12-, and 24-week intervals was similar to or greater than the June 1982 tiller density. When counts were made in December 1983, 18 months later after the start, maidencane in both nonfertilized and fertilized treatments had lower tiller density than June 1982 values. Tiller 


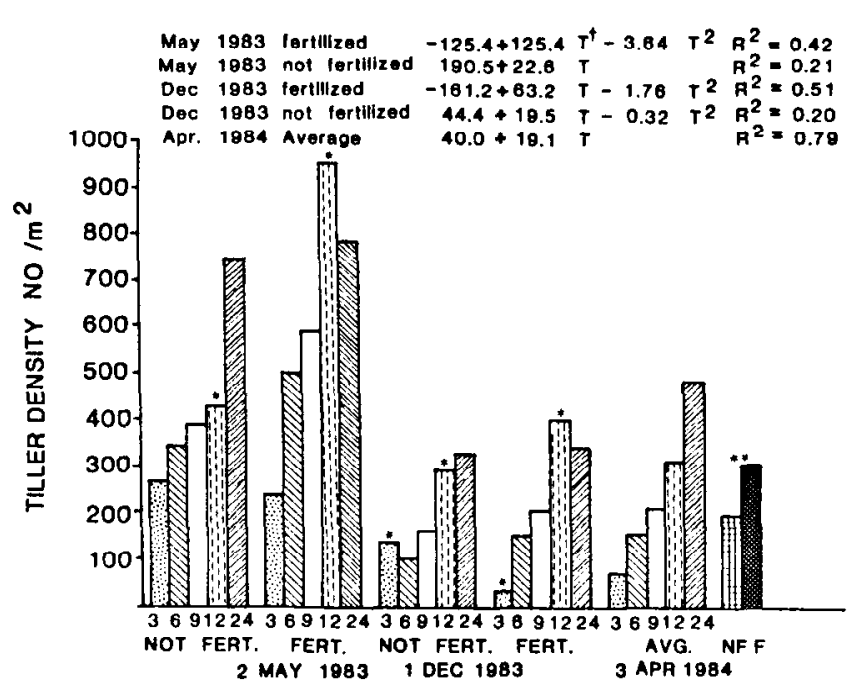

INTERVAL BETWEEN HARVEST, WEEKS

Fig. 2. Tiller density (observed) and prediction equations for tiller density of maidencane with and without fertilization. Bartow, Florida. 1983 and 1984.

$\dagger T=$ weeks between harvest.

* Difference between fertilized and not fertilized within the same cutting intervalare different $(\mathrm{P}<0.01)$. Fertilization was $56,12,22 \mathrm{~kg} / \mathrm{ha} N, P, K$ every 6 weeks.

**Difference between average fertilized $(F)$ and nonfertilized $(N F)$ different $(\mathrm{P}<0.01)$.

density of fertilized maidencane cut at 12-week intervals was greater than that of unfertilized maidencane on both 2 May and 1 Dec. 1983.

Tiller density was lower in more frequently harvested plots on 3 Apr. 1984 regardless of fertilizer treatment (Fig. 2). Fertilized plots had greater average tiller density than unfertilized plots. Comparison of tiller density at 3 Apr. 1984 or 1 Dec. 1983 with that on 2 May 1983 is difficult because counts were not made at similar times of the year. Maidencane was going into dormancy on 1 Dec. and had not completely initiated regrowth on $3 \mathrm{Apr}$.

\section{Rhizome TNC and Yield}

Rhizome TNC content and yield (Fig. 3) followed patterns similar to whole-plant yield (Fig. 1) and tiller density (Fig. 2). Predicted rhizome TNC and yield were quadratic over cutting frequencies and had low values at 3- to 9-week cutting intervals.

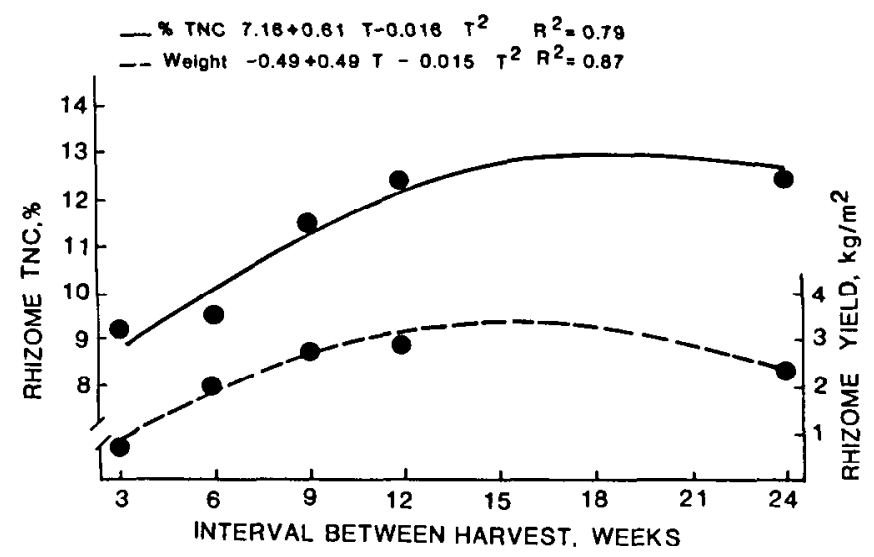

Fig. 3. Predicted and observed maidencane rhizome total non-structural carbohydrate (TNC) content and fresh weight yield as affected by interval ( $T=$ weeks) between harvest. Bartow, Florida. 1982 and 1983.
Maximum rhizome yield was predicted to occur at 12- to 18-week intervals, with a decline by the 24 -week interval. Predicted rhizome TNC continued to rise slowly in plants cut at intervals greater than 12 weeks. There was no rhizome yield or TNC response to fertilization and no interaction. Low TNC values indicate maidencane was not maintaining enough carbohydrate to sustain vigor, especially at 3-week intervals. Even though maidencane rarely flowers (early June), it maintains the morphology of grass (culm and cauline leaves) in the jointing stage. When maidencane was cut at $7.5 \mathrm{~cm}$, tillers were killed, and all new growth came from below ground.

\section{Forage Quality}

Crude protein content of maidencane in both fertilizer treatments declined as cutting interval increased in both years (Fig. 4).

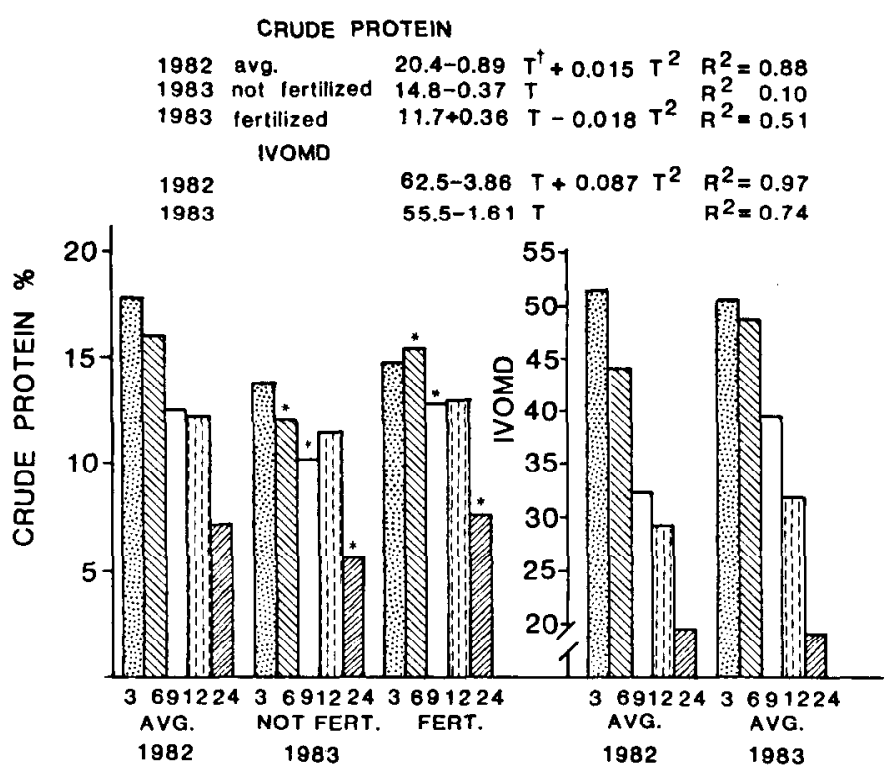

INTERVAL BETWEEN HARVEST, WEEKS

Fig. 4. Observed crude protein and in vitro organic matter digestibility (IVOMD) and their prediction equations for maidencane with and without fertilization. Bartow, Florida. 1982 and 1983.

$\dagger T=$ weeks between harvest.

* Difference between fertilized and not fertilized within the same cutting interval are different $(\mathrm{P}<0.05)$. Fertilization was $56,12,22 \mathrm{~kg} / \mathrm{ha} \mathrm{N}, P, K$ every 6 weeks.

The decline was about $0.5 \%$ in CP for each week that maidencane remained uncut after an initial 3-week period (height of 30 to 45 cm). Fertilization did not affect CP content in 1982, but in 1983 fertilization increased CP content (independent of cutting interval) $(P<0.01)$ over nonfertilized maidencane. When maidencane was fertilized in 1983, CP content was higher than unfertilized grass at 6-, 9-, and 24-week intervals. Maidencane sampled in December at the 24-week growth interval in both years had been senescent for 6 weeks prior to the first December frost.

Cutting interval affected $(P<0.01)$ IVOMD, which declined as much as $3 \%$ for every week that defoliation was postponed (Fig. 4). There was a steady IVOMD decline in 1983 when IVOMD dropped $1.6 \%$ for every week between 3 and 24 weeks. Poor digestibility has been reported for hand-collected upper leaves and stems and for bolus samples from esophageally fistulated steers grazing maidencane in winter (Long et al. 1986a). The decline in both CP and IVOMD in winter emphasizes the importance of maidencane use in summer (Kalmbacher et al. 1984, Long et al. 1986a).

Fertilization improved $(P<0.01)$ IVOMD in 1982 , but improvement was of little practical importance $(34.7 \%$ vs $36.2 \%)$. There 
was no fertilization effect $(P>0.05)$ on IVOMD in 1983.

Two-year average $C P$ was $12 \%$ for nonfertilized and $13.3 \%$ for fertilized maidencane and 36\% IVOMD for fertilized and $37 \%$ for unfertilized maidencane. Differences due to fertilization were small by comparison to effects that cutting frequency had on both $C P$ and IVOMD.

\section{Mineral Content}

There were no differences between fertilized and unfertilized plots $(P>0.05)$ in soil $P$ and $K$ content, which averaged 12 and 11.7 $\mathrm{kg} / \mathrm{ha}$ of $\mathrm{P}$ and $\mathrm{K}$, respectively. Soil Ca content and $\mathrm{pH}$ were lower $(P<0.01)$ on fertilized ( $495 \mathrm{~kg} /$ ha and 5.6) compared to unfertilized soil ( $547 \mathrm{~kg} / \mathrm{ha}$ and 6.0$)$. These analyses represent soil sampled over the 2-year experimental period.

There were no differences in $\mathbf{P}$ or $\mathbf{K}$ between fertilized and unfertilized maidencane during 1982. Likewise, tissue $P$ was not different between these treatments in 1983 , but $\mathrm{K}$ was higher in fertilized tissue $(1.1 \%)$ vs unfertilized tissue $(0.9 \%)$.

To determine how long fertilization effects could be detected, tissues from fertilized maidencane cut at repeated 3-week intervals were compared. Bearing in mind that fertilization was every 6 weeks, first-cut grass 3 weeks after fertilization was higher $(P<0.05)$ in $P$ content $(0.36 \%)$ than second-cut, 3-week old grass $(0.30 \%)$ in 1983 but not in 1982 . Tissue $K$ content was higher at 3 weeks (1.6\%) vs 6 weeks (1.3\%) in both years. Applied K usually does not accumulate on Florida's coarse textured soils, even when crop removal is small or when recycling occurs (Blue 1974).

Tissue $P$ and $K$ declined $(P<0.01)$ in each year as maidencane culms aged (Table 2). Because maidencane was fertilized every 6

Table 2. Effect of harveat interval on $P$ and $K$ content in whole plant maideneane forage (on dry matter basis).

\begin{tabular}{lcccc}
\hline \hline & \multicolumn{4}{c}{ Harvest interval (wks) } \\
\cline { 2 - 5 } Year/mineral & 3 & 6 & 9 & 12 \\
\hline & & & & \\
1982 & 0.34 & 0.33 & 0.28 & 0.16 \\
$\mathbf{P}^{1}$ & 1.59 & 1.38 & 1.22 & 0.40 \\
$\mathbf{K}^{2}$ & & & & \\
1983 & 0.30 & 0.34 & 0.27 & 0.12 \\
$\mathbf{P}^{3}$ & 1.00 & 1.48 & 1.19 & 0.21 \\
$\mathbf{K}^{4}$ & & & &
\end{tabular}

$\mathrm{IP}=0.3+2.1 \times 10^{-5} \mathrm{D}-9.0 \times 10^{-6} \mathrm{D}^{2}$

$2 \mathrm{~K}=1.5-7.5 \times 10^{-4}-5.0 \times 10^{-5} \mathrm{D}^{2}$

$3 \mathrm{P}=1.0+7.5 \times 10^{-4} \mathrm{D}-1.8 \times 10^{-6} \mathrm{D}^{2}$

$4 \mathrm{~K}=0.4+0.037 \mathrm{D}-7.43 \times 10^{-4} \mathrm{D}^{2}+3.0 \times 10^{-6} \mathrm{D}^{\mathrm{s}}$

Where $D$ is Julian date of harvest $(196,237,279,341$ for 1982 and $209,229,272,335$ for 1983) minus 196 , which makes the first sample date $D=0$.

weeks, forage cut on 9- and 12-week intervals received 2 applications compared to single applications on 3-and 6-week treatments (Table 1). Still, there was a steady decline in tissue $\mathbf{P}$ and $\mathrm{K}$. The decline was brought about by nutrient leaching from the soil, reduced uptake with plant age, and by dilution in increasing plant biomass. Grass at 12 weeks of age was especially low in $P$ and $K$ because of leaf senesence.

\section{Management Implication}

These data suggest that summer-long grazing of maidencane range at low stocking rates may not take advantage of the yield and quality potential of the grass just as deferring use through summer would not be taking advantage of the full potential of maidencane. Rotationally grazing at high grazing pressure with 5- to 7-week regrowth periods may be a compromise between yield, persistence, and quality. Fertilization with $N, P$, and $K$ at the rates, frequency, and soil used in this study would not be justifiable for improvement in yield or quality. Fertilization did help to lessen decline in yield and tiller density that resulted from more frequent defoliation.

\section{Literature Cited}

Blue, W.G. 1974. Utilization of residual nutrients accumulated in Florida's acid flatwoods soils under fertilized white clover-Pensacola bahiagrass pasture. Proc. XII Int. Grassl. Congr. (Moscow, Russia). Chemicalization in Grassland Farming. Vol. II p. 29-39.

Duval, V.L., and H.E. Grelen. 1967. Fertilization uneconomical for forage improvement in Louisiana pine-plantations. USDA Forest Serv. Res. Note. S0-51. Southern Forest Exp. Sta. New Orleans, La.

Gallaher, R.N., C.O. Weldon, and J.G. Futral. 1975. An aluminium block digester for plant and soil analysis. Soil Sci. Soc. Amer. Proc. 39:803-806.

Hambelton, L.G. 1977. Semiautomated method for simultaneous determination of phosphorous, calcium and crude protein in animal feeds. J.A.O.A.C. 60:845-852.

Jackson, M.L. 1958. Soil chemical methods. Prentice-Hall, Inc. Englewood Cliffs, NJ.

Kalmbacher, R.S., K.R. Long, M.K. Johnson, and F.G. Martin. 1984. Botanical composition of the diets of cattle grazing south Florida rangelands. J. Range Manage. 37:334-340.

Killinger, G.B. 1948. Effect of burning and fertilization of wiregrass on pasture establishment. Agron. J. 40:381-384.

Lewis, C.E. 1970. Responses to chopping and rock phosphate on south Florida ranges. J. Range Manage. 23:276-282.

Long, K.R., R.S. Kalmbacher, and F.G. Martin. 1986a. Diet quality of steers grazing 3 range sites in south Florida. J. Range Manage. 39:389-392.

Long, K.R., R.S. Kalmbacher, and F.G. Martin. 1986b. Effect of season and regrazing on diet quality of burned Florida range. J. Range Manage. 39:518-521.

Moore, J.E., and G.O. Mott. 1974. Recovery of residual organic matter from in vitro digestion of forages. J. Dairy Sci. 57:1258-1259.

Smith, D. 1969. Removing and analyzing total nonstructural carbohydrates from plant tissue. Wis. Agr. Exp. Sta. Res. Rep. 41.

Somogyi, M. 1952. Notes on sugar determination. J. Biol. Chem. 195-19-23.

Williams, R.E. 1951. Paille Fine. J. Range Manage. 4:171-172. 